\title{
Safe Food Handling: Knowledge, Perceptions, and Self-Reported Practices of Turkish Consumers
}

\author{
F. Gul Aygen ${ }^{1}$ \\ ${ }^{1}$ Department of Business Administration, Dogus University, Istanbul, Turkey \\ Correspondence: F. Gul Aygen, Faculty of Economics and Administrative Sciences, Department of Business \\ Administration, Dogus University, Acibadem, 34722, Kadikoy, Istanbul, Turkey. Tel: 90-216-544-5555. E-mail: \\ gaygen@dogus.edu.tr
}

\author{
Received: July 27, 2012 Accepted: October 31, 2012 Online Published: November 9, 2012 \\ doi:10.5539/ijbm.v7n24p1 URL: http://dx.doi.org/10.5539/ijbm.v7n24p1
}

\begin{abstract}
This study examines Turkish consumers' perceptions and knowledge of safe food handling practices. Their attitudes, opinions, and self-reported practices in the purchase, transportation, storage, preparation, and consumption of food were studied. Data was collected from a total of 440 consumers living in Istanbul, Turkey through the use of a self-administered, structured, and undisguised questionnaire. A combination of stratified and systematic random sampling was used based on the incidence of having or not having experienced food-related illness within the past year. Significant differences were found to exist in the perceptions, opinions, knowledge, and self-reported practices of those who had experienced food-borne illness in the past twelve months versus those who had not. Significant differences were also found with respect to various demographic variables, especially, with respect to age and education levels. Implications of the study for various parties, namely, consumers, producers, retailers, and the state together with further research are also presented in the paper. These implications may be applicable in different countries as well, since food-borne diseases experienced due to bad food-handling practices still present a major challenge to peoples' health, in both the developed and the developing world.
\end{abstract}

Keywords: consumer perceptions, knowledge, self-reported practices, safe food handling

\section{Introduction}

Today, thanks to rapid advances in food technology, processing and packaging techniques, extensive precautions are taken throughout the entire food chain to ensure the safety of foods. Through the use of quality management systems like Good Manufacturing Practices (GMP), Hazard Analysis Critical Control Points (HACCP), and Quality Assurance Standards, the food processing industry is able to produce high quality and safe products. The above-mentioned systems also enable quality assurance procedures at each level of the food chain, from suppliers and transporters to wholesalers and retailers, in the successive stages. Yet, in spite of these advances, potentially harmful microorganisms and chemicals occur naturally from time to time, leading to contamination and illnesses, if food is handled improperly (The European Food Information Council [EUFIC], 2010).

According to the World Health Organization (WHO), up to $30 \%$ of the populations of developed countries are affected by foodborne illness each year; more than 75 million people get sick from food related illnesses in the USA resulting in 325,000 hospitalizations and 5,000 deaths annually (WHO, 2007). In these countries, errors made in food preparation in the home, in restaurants, and other public places emerge as important causes of foodborne disease (EUFIC, 2010). The problem is likely to be even more widespread in developing countries where food contamination also occurs as a result of poor or inadequate production practices. As WHO further notes, foodborne diseases affect people's health and well-being significantly and have economic consequences for the society as a whole. They impose a substantial burden on health-care systems and reduce economic productivity. Moreover, as most of these cases are not reported, the true dimension of the problem is not known (WHO, 2007).

Both the European Union and WHO state that food safety is the shared responsibility of all parties involved from 'farm to fork'/'farm to table' and consumers need to understand and follow basic guidelines in purchasing, transporting, storing, preparing, and consuming food so as to maintain both their individual and societal well-being (EUFIC, 2010). 


\section{Literature Review}

The topic of food handling, knowledge, attitudes, and self-reported practices of consumers together with their actual food-handling behaviors have been studied by various researchers over time. In all of these studies, consumers were found to be aware of some safe food handling practices but lacked knowledge of others. As such, it was concluded that consumer knowledge of food safety was inadequate and required improvement in most instances (Redmond \& Griffith, 2003). Temperature control, especially in the case of defrosting frozen foods is one of the areas which seems to present a major challenge in many societies (Bruhn \& Schutz, 1999; Knight, Jackson, Bain, \& Eldemire-Shearer, 2003; Badrie, Gobin, Dookeran, \& Duncan, 2006; McCarthy et al., 2007; Boodhu, Badrie, \& Sookdhan, 2008; Jevšnik, Hlebec, \& Raspor, 2008; Odwin \&Badrie, 2008). Still, a large proportion of consumers seems to either lack knowledge concerning adequate refrigeration temperatures or do not check the temperatures of their refrigerators. (Worsfold \& Griffith, 1997; Cody \& Hogue, 2003; Knight et al. 2003; Redmond \& Griffith, 2003; Badrie et al., 2006; US Food and Drug Administration [FDA], 2006; Jevšnik et al., 2008). Food thermometers do not seem to be widely used (Cody \& Hogue, 2003; Badrie et al., 2006; FDA, 2006). Awareness with respect to bacteria causing food-related illnesses was also found to be rather low, especially in the case of Campylobacter (Redmond \& Griffith, 2003; FDA, 2006).

In general, women were found to be safer in their food handling practices compared to men (Altekruse, Yang, Babagaleh, \& Angulo, 1999; Angelillo, Foresta, Scozzafava, \& Pavia, 2001; Li-Cohen \& Bruhn, 2002; Jevšnik et al., 2008) and older adults were safer compared to younger adults (Altekruse et al., 1999; Angelillo et al., 2001; Li-Cohen \& Bruhn, 2002). On the other hand, no significant differences were reported with respect to gender and income level in most of the food safety issues investigated in the Knight et al. study (2003). Education and income levels were found to have significant contradictory effects in different studies: Whereas in Li-Cohen and Bruhn's study (2002), lower-income and medium-level education (less than college) were safer in food handling than households with higher income and individuals with college and further education, Zhang, Lando, Estrin, and Levy (2010) have found that education had no effect on food handling practices in Costa Rica and the more affluent consumers reported safer food handling practices than the low income group; in the USA, income had no effect on food handling and women who had a medium level of education tended to be safer in their food handling. The rich and the more educated women consumed more risky foods in the US but not in Costa Rica. Prevalence of some risky behavior was found to increase with increasing socioeconomic status in Altekruse et al.'s study (1999). Interestingly, in both the Knight et al. (2003) and Unusan (2007) studies, males were found to be more involved with food handling and preparation at home, compared to earlier times.

In many studies, the majority of respondents indicated that hand washing is a necessary food safety practice and that after handling raw meat, poultry, or fish, it is necessary to clean hands by washing them with soap and (warm) water (Knight et al., 2003; FDA, 2006; McCarthy et al., 2007; Odwin \& Badrie, 2007; Jevšnik et al., 2008). About 65 to $80 \%$ of the respondents stated that after raw meat/chicken is cut on a cutting board and before handling other foods that will be eaten raw, it is necessary to wash the cutting board with soap or in a dishwasher (Badrie et al., 2006; FDA, 2006; Knight et al., 2007). Nevertheless, there is always the possibility that people do not do what they say and observational studies suggest, in fact, that large numbers of consumers fail to wash and dry their hands adequately after handling raw chicken (Redmond \& Griffith, 2003). Yet, as Cody and Hogue (2003) point out, although knowledge and self-reported behavior do not always correspond to actual behavior, they provide evidence of what consumers know and of how consumers apply this information in their decision-making, even if their actual behavior falls short of their knowledge of good practice. Besides, "information obtained from consumers can be used to shape educational programs and to motivate consumers to make healthful changes in their food-handling and sanitation behaviors" (p.1115).

\section{Research Design and Methodology}

\subsection{Research Purpose and Design}

The purpose of this study is to examine Turkish consumers' perceptions and knowledge of safe food handling practices. More specifically, their attitudes, opinions, and self-reported practices in the purchase, transportation, storage, preparation, and consumption of food will be studied. It is important to study food safety and related topics which are less-researched areas in Turkey but will be gaining more importance in the near future, as Turkey's ties with the European Union will necessitate new considerations and applications on "food".

The research questions for which answers are sought can be stated as follows:

- What are Turkish consumers' opinions regarding the importance of maintaining safe and hygienic conditions while preparing foods at home? 
- What are the perceptions of Turkish consumers concerning their knowledge of preparing safe foods in their homes?

- What is the knowledge level of Turkish consumers with respect to safe food handling practices during purchase, transportation, storage, preparation, and consumption of food?

- Is there any significant difference in the knowledge, perceptions, and self-reported practices of those who have experienced and those who have not experienced any food-borne illness within the past twelve months?

- Is there any significant difference in the knowledge, perceptions, and self-reported practices of both male and female respondents? Are there significant variations in the knowledge, perceptions, and self-reported practices of consumers across different income levels, education levels, working status, and household composition (age categories, presence of children under five years of age)?

This research is descriptive in nature, as it attempts to describe the prevailing opinions, perceptions, knowledge levels, attitudes, and self-reported practices of Turkish consumers regarding the topic of food handling.

\subsection{Data Collection Procedure and Instrument}

Data was collected through a self-administered, structured, and undisguised questionnaire distributed among consumers. Questions were developed upon a thorough analysis of relevant literature. A pilot study was carried out among 20 consumers to see if the questions were readily understood. Necessary changes were made in the wording of some questions before distributing the questionnaires for the actual study. The questionnaire was composed of 20 questions apart from the demographics and took an average of 15 minutes to administer. The internal reliability of the questionnaire using the Cronbach's alpha coefficient was 0.89 , which indicated a high internal correlation among the items. The content validity in meeting the objectives of the study was established on consultation with food engineers and the literature.

\subsection{The Sampling Design}

The questionnaires were distributed to consumers living in Istanbul. This cross-sectional field study took place during the two months of March and April 2010.

A combination of stratified and systematic random sampling was used. A total of 440 individuals were recruited by a local market research company, all of whom responded to the questionnaire. The company used its own databank and every third person was questioned as to whether they had food-related illness within the preceding year or not. A total of 142 "sufferers" volunteered to take part in the study and filled in the questionnaire. As most people could only talk about having experienced a food-related illness and did not really know about the exact bacteria/virus that caused their sickness, they could not be categorized into separate strata.

Table 1. Sample characteristics

\begin{tabular}{llrr}
\hline & & Frequency & Valid \% \\
\hline Gender & Female & 293 & 66.6 \\
Age & Lale & 147 & 33.4 \\
& Less than 20 & 15 & 3.4 \\
& $20-29$ & 127 & 29.0 \\
$30-39$ & 139 & 31.7 \\
& $40-49$ & 72 & 16.5 \\
& $50-59$ & 42 & 9.6 \\
Income & and above & 43 & 9.8 \\
& Missing & 2 & \\
Very low & 12 & 2.7 \\
Low & 76 & 17.6 \\
& Medium & 308 & 71.1 \\
& High & 35 & 8.1 \\
Very high & 2 & 0.5 \\
Missing & 7 & \\
\hline
\end{tabular}




\begin{tabular}{llrr}
\hline Education & Primary school & 93 & 21.2 \\
& Secondary school & 61 & 13.9 \\
& Senior high school & 110 & 25.2 \\
& University & 131 & 29.9 \\
& Post graduate & 43 & 9.8 \\
& Missing & 2 & \\
Working status & Full-time & 246 & 56.1 \\
& Part-time & 15 & 3.3 \\
& Not working & 178 & 40.6 \\
Missing & 1 & \\
Presence of child / children under 5 years of age & & \\
& Yes & 49 & 12.9 \\
& No & 331 & 87.1 \\
Missing & 60 & \\
Incidence of having foodborne illness within the preceding year & & \\
$\quad$ Yes & 142 & 32.3 \\
& No & 298 & 67.7 \\
\hline
\end{tabular}

Demographic characteristics of the respondents are presented in Table 1. Two thirds of the respondents were women. About one third of the sample was in their thirties and another one third, in their twenties. Those who were middle income consumers made $71 \%$ of the sample. Concerning education levels, one fifth of the sample were elementary school, one fourth were senior high school, and one third were university graduates. A little more than $10 \%$ of the sample had children less than five years of age. $30 \%$ had experienced a food-borne illness within the past year.

\subsection{Analysis of Data}

The analysis of the 440 questionnaires, inclusive of the descriptive statistics (frequency distributions and cross-tabulations) and the relevant tests to investigate the various relationships and differences sought among the variables included in the study, were completed by using the computer program, Statistical Package for the Social Sciences.

\section{Findings}

\subsection{Descriptive Results}

\subsubsection{General Findings}

With respect to the importance given by Turkish consumers to safe and hygienic food preparation conditions at home, for $75.4 \%$ of the respondents, this was a "very important" consideration, for $23.9 \%$ it was "important", for only $0.7 \%$ it was "not important". There was no one who thought this consideration "not to be important at all". As to whether people believed they had sufficient knowledge of preparing safe food in their homes, $76.1 \%$ replied affirmatively, whereas only $16 \%$ replied negatively.

Regarding the frequency of cooking food in their homes, about $70 \%$ of the sample cook "all or nearly all of the time", whereas about $30 \%$ either "cook some of the time" or "never".

As much as $32.3 \%$ of the respondents have indicated that they had experienced food-related illness within the preceding year and $40.1 \%$ of these respondents thought that the cause was food eaten at a restaurant, $30.3 \%$ thought that it was because of a food item purchased on the street, and $26.1 \%$ thought that it was because of food prepared and eaten at home. $3.5 \%$ gave other reasons.

Approximately $72 \%$ of those respondents who had experienced food-related illness during the preceding year indicated that they had informed the following on this incidence: $59.8 \%$ told the doctor, $42.2 \%$ their friends/relatives, $16.7 \%$ a hospital, $12.7 \%$ the place from which the food was purchased, $3.9 \%$ the producer, $2.9 \%$ the place where the food was eaten, and $1.0 \%$ the Ministry of Health. With respect to temperature control, for $39.8 \%$ of the respondents, it is "very important" to know the internal temperature of their refrigerator, for 
$48.5 \%$, it is "quite important", whereas for $3.2 \%$, it is "quite unimportant" and for $0.2 \%$, it is "not important at all". 8.3\% have "no idea" on this. Even though the majority of respondents (about $88 \%$ ) thought this to be "very/quite important", only 50.6\% stated that their refrigerator had a thermometer indicating the internal temperature of the fridge while $35.5 \%$ stated that it did not have such a thermometer. $13.9 \%$ indicated that they had not looked to see if there was such a thermometer in/on their refrigerators. Of those who indicated that there was a thermometer, $45.5 \%$ knew the correct temperature at which a refrigerator should operate (up to $5^{\circ} \mathrm{C}$ ).

Only $1.8 \%$ of the respondents indicated that they were using a food thermometer while cooking. Only $9.0 \%$ believed that it was "very important", $24.5 \%$ that it was "quite important", $9.2 \%$ that it was "quite unimportant", and $18.2 \%$ that it was "not important at all" to use a food thermometer while cooking. $39.1 \%$ stated that they did not have any idea on this issue. When asked if they have consumed a food product containing raw eggs (such as mayonaise, desserts, pastry) within the last year, $44.5 \%$ replied "yes", $46.8 \%$ replied "no", and $8.6 \%$ indicated that they could "not remember". These percentages were 14.2, 83.7 and 2.1, respectively for the consumption of raw hotdogs within the preceding year.

With respect to levels of respondents' knowledge regarding bacteria/viruses that cause food related illnesses, a majority seems not to have heard of Listeria (73.8\%), Campylobacter (73.4\%), and Salmonella (61.0\%). The most commonly known virus is Hepatitis A (79.5\%) followed by E-coli bacteria (66.7\%), and Vibrio bacteria $(60 \%)$ (Figure 1).

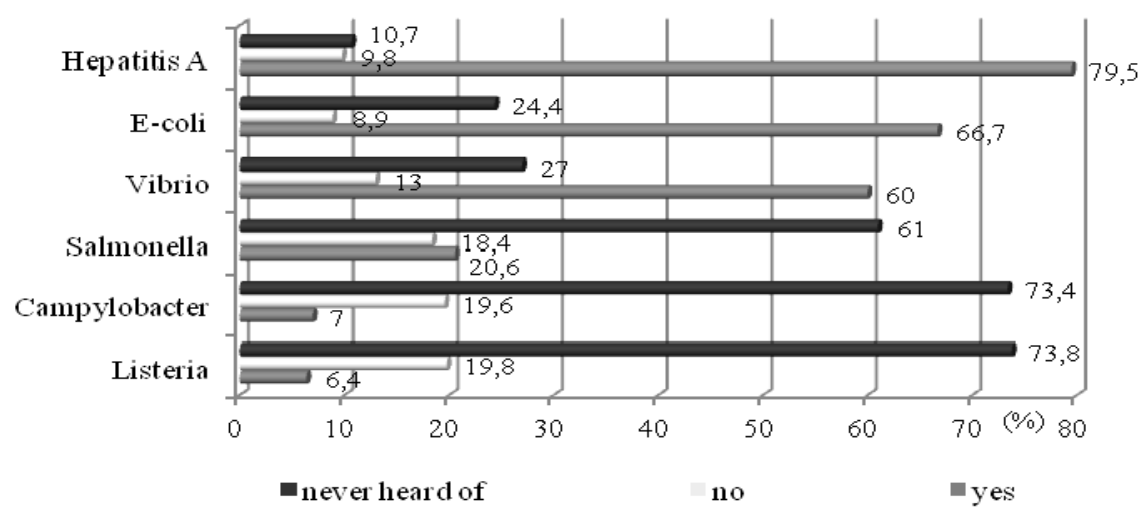

Figure 1. Knowledge of bacteria/viruses that cause food-related illnesses

4.1.2 Findings Related to Knowledge and Self-reported Practices Regarding Food Handling During Purchase, Storage, Preparation, and Consumption of Food

Table 2 reveals the results related to knowledge and self-reported practices regarding food handling during purchase, storage, preparation, and consumption of food.

Table 2. Knowledge and self-reported practices regarding food handling

\begin{tabular}{lccccccc}
\hline & Always & Frequently & Sometimes & Seldom & Never & Do not know \\
\hline $\begin{array}{l}\text { Purchase swollen or dented cans } \\
*(\mathrm{n}=438)\end{array}$ & 1.4 & 0.2 & 1.4 & 4.8 & 89.4 & 2.8 \\
$\begin{array}{l}\text { Check for the expiry dates on labels } \\
\text { before purchase (n=437) }\end{array}$ & 60.3 & 26.3 & 9.5 & 1.8 & 2.1 & --- \\
$\begin{array}{l}\text { Examine food packages to see if they } \\
\text { have been opened or damaged (n=437) }\end{array}$ & 68.7 & 23.3 & 5.9 & 1.4 & 0.7 & --- \\
$\begin{array}{l}\text { When purchasing frozen foods, check to } \\
\text { be sure they are frozen solid (n=438) }\end{array}$ & 41.1 & 30.4 & 17.4 & 5.3 & 1.8 & 4.0 \\
$\begin{array}{l}\text { Check for the temperature of the cooler in } \\
\text { the supermarket (n=437) }\end{array}$ & 8.9 & 15.6 & 31.1 & 19.0 & 19.7 & 5.7 \\
$\begin{array}{l}\text { Put frozen foods away immediately on } \\
\text { reaching home (n=436) }\end{array}$ & 71.4 & 22.0 & 3.9 & 0.9 & 1.1 & 0.7 \\
\hline
\end{tabular}


Check the refrigerator / freezer from time to time to ensure that it is within the required temperature $(n=437)$

$\begin{array}{llllll}23.6 & 27.9 & 32.5 & 9.2 & 3.4 & 3.4 \\ 46.8 & 35.8 & 8.2 & 3.0 & 3.7 & 2.5 \\ 3.7 & 1.8 & 2.5 & 3.2 & 86.5 & 2.3 \\ 45.6 & 33.7 & 17.7 & 2.1 & 0.7 & 0.2 \\ 2.1 & 0.7 & 3.9 & 2.6 & 88.6 & 2.1 \\ 23.3 & 18.0 & 28.1 & 15.7 & 13.7 & 1.2 \\ 3.5 & 4.8 & 15.4 & 13.7 & 57.8 & 4.8 \\ 2.1 & 2.5 & 15.6 & 23.3 & 55.1 & 1.4\end{array}$

Store legumes at a cool, dry, and dark place $(\mathrm{n}=437)$

Store legumes and flour close to detergents/soaps* $(\mathrm{n}=436)$

Follow storage, preparation, and other instructions on the product labels $(\mathrm{n}=435)$

Use same plate for raw and cooked meat, do not wash plate before using it for cooked meat $*(\mathrm{n}=438)$

Taste leftovers to check if they are still safe* $(\mathrm{n}=434)$

Use raw eggs in salad, dessert, and drinks* $(\mathrm{n}=434)$

Consume food that has mold on it after throwing away the moldy section $*(\mathrm{n}=437)$

*Unsafe practices are given in italics.

**The first five statements are related to knowledge and self-reported practices during purchase, the next four during storage, and the last five during preparation and consumption.

With respect to handling practices during purchase, there seems to be some knowledge problems, except for the "(non)purchase of swollen/dented cans". In that instance, a great majority of the respondents $(89 \%)$ have correctly indicated that they "never" bought such products. However, in case of the other statements, although there are knowledgeable respondents, there are also non-knowledgeable ones and their percentages are not low. The percentage of those respondents who do not "always" "examine food packages to see if they have been opened/damaged" is about $30 \%$, those who do not "check for expiry dates" is about $40 \%$, those who do not "check frozen foods to be sure that they are frozen solid" is about $60 \%$, and those who do not "check the temperature of the cooler in the supermarket" is about $90 \%$.

There also seem to be some knowledge problems with respect to storage: Only $24 \%$ of the respondents have indicated that they "always" "checked the refrigerator/freezer from time to time to ensure that it is within the required temperature". Besides, those who "always" "put frozen foods away immediately on reaching home" and "store legumes at a cool, dark, and dry place" make up $71 \%$ and $47 \%$ of the sample respectively, which cannot be considered to be very high, either, with respect to knowledge levels of individuals. On the other hand, "(non)storage of legumes and flour close to detergents and soaps" seems to be known by a great majority of the respondents.

Most of the respondents (89\%) seem to know that "the same plate cannot be used for both raw and cooked meat, before being washed". Yet, in case of other practices related to preparation or consumption of foods, appropriate replies do not reach high percentages, again indicative of rather less knowledgeable responses. About $40 \%$ "use raw eggs in salads, desserts, and drinks", $45 \%$ "consume food that has mold on it after throwing away the moldy section", $54 \%$ do not "follow instructions on product labels", and $85 \%$ "taste leftovers", at least from time to time.

Two other questions that were related to self-reported food-handling practices were the following:

When I need to defrost frozen foods, I take it out of the freezer and put it... $(n=440)$

$\begin{array}{ll}\text { On the countertop } & 54.3 \% \\ \text { In the refrigerator* } & 35.7 \% \\ \text { In a bag in warm water } & 7.7 \% \\ \text { I do not use frozen foods } & 3.4 \%\end{array}$


In the microwave*

$3.0 \%$

(Use frozen foods that need not be defrosted before use)

$1.1 \%$

(Some respondents have signed more than one option).

After raw meat/chicken is cut on a cutting board, before handling other foods that will be eaten fresh $(n=434)$

It is necessary to wash the cutting board with soap or in a dishwasher* $\quad 74.2 \%$

It is sufficient to rinse it before use $\quad 16.6 \%$

It is sufficient to wipe it before use $\quad 5.1 \%$

I am not sure $\quad 2.7 \%$

It is okey to cut on the same board without cleaning it at all $1.4 \%$

*: The correct answers

The finding with respect to "defrosting of frozen foods" is quite frustrating as more than $50 \%$ of the respondents have indicated that they thawed frozen foods on the countertop, while about $8 \%$ did so in a bag dipped in warm water. Fresh foods that will be cut on a cutting board after raw meat/chicken is cut on the board also deserve attention: Even though $74 \%$ of the respondents replied correctly, $17 \%$ have indicated that rinsing it would be sufficient, $5 \%$ that wiping it would be sufficient, and about $1 \%$ that the same board could be used without doing anything.

\subsubsection{Findings Related to Other Food Safety Knowledge Related Statements}

Other food safety knowledge related statements the respondents were presented with are given in Table 3 .

Table 3. Food safety knowledge statements

\begin{tabular}{|c|c|c|c|c|c|c|}
\hline & $\begin{array}{l}\text { Strongly } \\
\text { Agree }\end{array}$ & Agree & $\begin{array}{l}\text { Neither Agree } \\
\text { Nor Disagree }\end{array}$ & Disagree & $\begin{array}{l}\text { Strongly } \\
\text { Disagree }\end{array}$ & $\begin{array}{l}\text { Do Not } \\
\text { Know }\end{array}$ \\
\hline $\begin{array}{l}\text { Freezing food kills all bacteria that may } \\
\text { cause illness } *(\mathrm{n}=432)\end{array}$ & 3.9 & 23.4 & 15.5 & 22.3 & 18.5 & 16.4 \\
\hline $\begin{array}{l}\text { Cooked food should be placed in the } \\
\text { refrigerator in two hours }(n=435)\end{array}$ & 22.3 & 45.6 & 12.6 & 9.9 & 1.1 & 8.5 \\
\hline $\begin{array}{l}\text { Leftover foods can be safely kept at room } \\
\text { temperature for several hours* }(n=436)\end{array}$ & 4.6 & 6.0 & 5.6 & 41.1 & 40.6 & 2.1 \\
\hline $\begin{array}{l}\text { All bacteria found in foods are harmful* } \\
(\mathrm{n}=432)\end{array}$ & 16.6 & 18.1 & 20.6 & 24.1 & 10.4 & 10.2 \\
\hline $\begin{array}{l}\text { To be healthy, food should be sterile before } \\
\text { being eaten* }(\mathrm{n}=433)\end{array}$ & 39.7 & 37.0 & 7.2 & 9.2 & 0.9 & 6.0 \\
\hline $\begin{array}{l}\text { The more you pay for a food product the } \\
\text { safer it is } *(\mathrm{n}=437)\end{array}$ & 5.7 & 9.4 & 16.0 & 39.4 & 27.0 & 2.5 \\
\hline $\begin{array}{l}\text { Feeding family pets in the kitchen presents } \\
\text { a food safety risk }(n=434)\end{array}$ & 56.7 & 26.5 & 5.3 & 4.8 & 5.1 & 1.6 \\
\hline $\begin{array}{l}\text { You can always tell that a food is unsafe to } \\
\text { eat by its appearance* }(\mathrm{n}=438)\end{array}$ & 10.7 & 29.5 & 19.9 & 28.0 & 10.5 & 1.4 \\
\hline $\begin{array}{l}\text { You can always tell that a food is unsafe to } \\
\text { eat by its smell* }(\mathrm{n}=439)\end{array}$ & 20.7 & 38.0 & 11.8 & 23.8 & 4.6 & 1.1 \\
\hline $\begin{array}{l}\text { I have to dry my hands after washing them } \\
(n=436)\end{array}$ & 41.7 & 43.2 & 9.6 & 2.8 & 2.1 & 0.6 \\
\hline $\begin{array}{l}\text { When beef is brown on the outside, it is } \\
\text { safe to eat } *(\mathrm{n}=436)\end{array}$ & 6.2 & 24.1 & 17.7 & 26.4 & 12.8 & 12.8 \\
\hline $\begin{array}{l}\text { We can put raw and cooked chicken into } \\
\text { the same container as long as it is kept in } \\
\text { the fridge* }(n=439)\end{array}$ & 3.4 & 3.9 & 0.9 & 23.2 & 64.5 & 4.1 \\
\hline
\end{tabular}




\begin{tabular}{|c|c|c|c|c|c|c|}
\hline $\begin{array}{l}\text { It does not matter if food warms up when } \\
\text { in the car if placed in the fridge or freezer } \\
\text { immediately once home* }(\mathrm{n}=437)\end{array}$ & 4.6 & 21.7 & 20.6 & 27.9 & 16.7 & 8.5 \\
\hline $\begin{array}{l}\text { Dishcloths can carry unsafe bacteria } \\
(\mathrm{n}=440)\end{array}$ & 39.8 & 45.7 & 8.4 & 3.2 & 1.6 & 1.3 \\
\hline $\begin{array}{l}\text { Cans have to be cleaned before they are } \\
\text { opened }(n=435)\end{array}$ & 48.5 & 40.7 & 6.4 & 1.8 & 1.4 & 1.2 \\
\hline $\begin{array}{l}\text { Cutting boards should not be made of } \\
\text { wooden material }(n=433)\end{array}$ & 16.6 & 31.6 & 24.7 & 10.6 & 6.2 & 10.3 \\
\hline $\begin{array}{l}\text { It will be unsafe to use a worn cutting } \\
\text { board,carrying scratches on it }(n=432)\end{array}$ & 31.1 & 41.4 & 15.3 & 5.1 & 1.6 & 5.5 \\
\hline
\end{tabular}

*Statements in italics reflect "incorrect" answers.

The following agreement rates ("strongly agree" and "agree" summed up) were obtained for the "incorrect" statements; "to be healthy, food should be sterile before it is eaten" (77\%), "you can always tell that a food is unsafe to eat by its smell" (59\%), "you can always tell that a food is unsafe to eat by its appearance" (40\%), "all bacteria found in foods are harmful" (35\%), "when beef is brown on the outside, it is safe to eat" (30\%), "freezing food kills all bacteria that may cause illness" (27\%), "it does not matter if food warms up when in the car if placed in the fridge or freezer immediately once home" (26\%).

Besides, more than $10 \%$ of the respondents indicated that they "did not have an idea" about the following statements: "freezing food kills all bacteria that may cause illness" (16\%), "when beef is brown on the outside, it is safe to eat" (13\%), "cutting boards should not be made of wooden material" $(10 \%)$, "all bacteria found in foods are harmful"(10\%).

Respondents seem to be most knowledgeable on the following: "cans have to be cleaned before they are opened" ( $89 \%$ agreement rate), "we can put raw and cooked chicken into the same container as long as it is kept in the fridge" ( $88 \%$ disagreement rate), "dishcloths can carry unsafe bacteria" ( $86 \%$ agreement rate), "I have to dry my hands after washing them" ( $85 \%$ agreement rate), "feeding family pets in the kitchen presents a food safety risk" ( $83 \%$ agreement rate), "leftover foods can be safely kept at room temperature for several hours" ( $82 \%$ disagreement rate).

\subsection{Results Supported by Statistical Tests (With Respect to the Demographic Variables and Experience of Food Borne Illness)}

Since all of the variables used in the study were found to be non-normally distributed, non-parametric tests were used (Mann-Whitney, Kruskal-Wallis). The Mann-Whitney U Test was used to test for significant differences in case of "gender" and the Kruskal-Wallis Test was used in case of "age", "education", and "income", with respect to the respective groups' self-reported food-handling practices and food safety knowledge in general. Findings related to the analyses of demographic variables are as follows: With respect to gender, there are not many statistically significant differences between men and women with respect to their knowledge and self-reported practices regarding food handling and also, with respect to their food safety knowledge. In case of the few differences, women seem to be more knowledgeable compared to men.

Besides, when asked about the importance they gave to having safe and hygienic conditions at home while preparing food, more women considered this to be "very important" compared to men $(79 \%$ vs $67 \%$, respectively) $\left(\lambda^{2}=11.885, \mathrm{p}=.003\right)$ and still in another question, more women were found to believe that they had "sufficient knowledge of safe food handling practices" compared to men ( $80 \% \mathrm{vs} 67 \%$, respectively) $\left(\lambda^{2}=9.268\right.$, $\mathrm{p}=.010)$. As can be expected, women cook much more often than men. $(80.1 \%$ of women $[45.2+34.9]$ have stated cooking "all or nearly all of the time" while only $19.9 \%[16.1+3.8]$ have stated cooking "only some of the time" or "never". Yet, an interesting finding is that $48.0 \%[19.9+28.1]$ of men have also reported cooking "all or nearly all of the time" whereas $52.0 \%[38.4+13.6]$ have reported cooking "only some of the time" or "never".

With respect to age, those respondents younger than 20 years of age seem to be the least knowledgeable on a variety of safe food handling practices. The older groups are more knowledgable about these issues. 
With respect to knowledge and self-reported practices regarding food handling and also, with respect to food safety knowledge, many significant differences exist with respect to education. Not surprisingly, knowledge and awareness of safe food handling practices increase as education level increases.

Besides this, responses to other questions on the questionnaire show that elementary school graduates consider "safe and hygienic conditions used in preparing food at home" to be less important than other graduates $(\mathrm{p}=.001)$ and they have experienced food-related illness within the past year more compared to university graduates $(\mathrm{p}=.010)$.

There are only a few statistically significant differences with respect to income. Lower income consumers tend to be less knowledgeable compared to middle and high income consumers, about these variables.

No statistically significant difference was found in case of the two variables, "having/not having children under 5 years of age" and "working status", with respect to their awareness, knowledge, and self-reported food handling practices.

In case of "experience of food-borne illness within the past year", it seems that those who had experienced illness (the "experienced") tend to think to a less extent about the importance of having "safe and hygienic conditions at home while preparing foods" compared to those who had not experienced such an illness (the "inexperienced") ( $80 \%$ of the "inexperienced" believe this to be "very important" whereas this percentage is 66 in case of the "experienced") $\left(\lambda^{2}=10.156, p=.006\right)$. With respect to knowledge and self-reported practices regarding food handling and also, with respect to food safety knowledge, the "experienced" have less safe food handling awareness, knowledge, and practices compared to the "inexperienced".

\section{Conclusions}

Turkish consumers' perceptions, knowledge, and self-reported practices regarding safe food handling were assessed in this study. Even though more than $75 \%$ of the respondents believed that they had sufficient knowledge of preparing safe food in their homes and a high rate of importance was given to safe and hygienic food preparation conditions at home, findings of the study were not that promising in the sense that knowledge of safe food handling among Turkish consumers was found not to be at a very satisfactory level.

Those who had experienced food-borne illness in the preceding year have less safe food handling awareness, knowledge, and practices compared to those who had not; yet, they also seem to think to a less extent about the importance of having "safe and hygienic conditions at home while preparing foods" compared to the other group. This points to the fact that if consumers are not knowledgeable enough about safe food handling and if they do not care about it, there is a high probability that they will be faced with food-related illnesses throughout their lives. So, consumers have to be aware of their responsibilities and need to know that they are one of the main actors in the "farm-to-fork" chain. As such, it is not the sole responsibility of the state to deal with the education of consumers; together with the state, consumers themselves and the industry (producers / manufacturers and retailers) all have significant roles to play.

Contrary to the findings of some other researchers (Fein, Jordan-Lin, \& Levy, 1995), 26\% of those individuals who had experienced a food-related illness within the preceeding year thought it was prepared and eaten at home, which indicates that people seem to admit that food prepared at home may also be the cause of such illnesses. This may be promising in the sense that if people admit that there may be something wrong with what they are doing (getting ill because of the food they themselves have prepared at their homes), they may be more willing to learn what to do in order not to get ill again. One other consideration is related to the finding that there are rather low levels of awareness among the respondents with respect to bacteria/viruses that cause food-related illnesses. We cannot expect someone to be afraid of something and take action to deal with it if he/she is not even aware of its existence. Hence, how can we expect the public to defend themselves against bacteria/viruses, given the fact that they are not even aware of the probability of a danger?

When such an illness is experienced, the doctor and relatives/friends seem to be the two parties who are most often informed about the situation. Negative word of mouth may result in severe consequences and a damaged reputation for the "faulty" producers/retailers/service providers (restaurants), in this instance. Hence, all of these parties should be extremely sensitive in their food handling practices and be aware of their responsibilities within the "farm-to-fork" chain.

Not surprisingly, women cook much more often than men; yet, $48 \%$ of men have also reported cooking "all or nearly all of the time". This means that almost half of the male respondents are involved with cooking quite frequently as well, implying that their safe food handling awareness and knowledge in fact is also quite an important consideration. This may present a possible problem given also the finding that men tend not to give 
importance to "having safe and hygienic conditions at home while preparing food" to the same extent as women. Hence, men should also be targeted with care in the preparation of educational programs.

Food handling, like many of our daily activities, rests on habits to a great extent. We tend to behave as we see what others do around us, right from our childhood. As such, our families and friends are very influential in shaping our lives. Habits are not easy to change; yet, if families are knowledgeable enough about food related matters, they will be passing this knowledge to their children without being aware of it and in the long-run, later generations will be adopting safe food handling practices as habits, without even being aware of it. Hence, inclusion of food safety education in school curricula is strongly recommended as today's children are tomorrow's parents. Besides, as consciousness increases in every aspect of life with higher education levels, further education should be encouraged among the public, if possible.

A nation-wide consumer education campaign launched by the joint efforts of the state, the food industry, and consumer groups may also be advisable. Similar programs that have been used in other countries -such as "FightBAC ("BAC" stands for "bacteria")" and "Home Food Safety... It's in Your Hands" in the USA or "Food Safety Week" in the UK- may be studied and adopted after being adapted to local needs (FightBAC, 2010). Through the joint effort of all involved, effective ways of reaching consumers may be found and key principles of food safety may be passed on to relevant parties through the use of informative leaflets, brochures, and the like.

Awareness with respect to safe food handling may also be increased by researchers through further research in this area. Even the questionnaire used for the present study aroused considerable attention among the respondents and induced them to begin thinking about what they were actually doing and what they ought not to. They were quite eager to learn about "correct" handling practices. Through regular research, food safety related awareness among the public may be increased, at least to an extent, and the progress can be checked over time. Findings should also be shared to the greatest possible extent, possibly using both print and broadcast media.

The findings of this study reflect food handling knowledge, perceptions, and self-reported practices of Turkish consumers; nevertheless, implications of the study may be applicable in different countries as well, since food-borne diseases experienced due to bad food-handling practices still present a major challenge to peoples' health, in both the developed and the developing world.

\section{Limitations}

Self-reported practices are blamed for possibly not reflecting actual behavior due to social desirability bias (Redmond \& Griffith, 2003); hence, inclusion of some self-reported practices in this study may be considered to be a limitation. Nevertheless, they provide valid information on awareness and whether consumers have at least some knowledge about "correct" behaviors even if they may not exercise these behaviors all of the time. Moreover, social desirability bias does not seem to present a severe problem in this particular study as self-reported practices of the sample includes rather high percentages of less appropriate/"incorrect" or "do not know" answers. The question at this point is not whether people are doing what they are saying but, instead, whether these people can somehow be made more knowledgeable about handling food safely.

\section{References}

Altekruse, S. F., Yang, S., Babagaleh, T. B., \& Angulo, F. (1999). A multi-state survey of consumer food-handling and food-consumption practices. American Journal of Preventive Medicine, 16(3), 216-221. http://dx.doi.org/10.1016/S0749-3797(98)00099-3

Angelillo, I. F., Foresta, M. R., Scozzafava, C., \& Pavia, M. (2001). Consumers and foodborne diseases: knowledge, attitudes and reported behavior in one region of Italy. International Journal of Food Microbiology, 64, 161-166. http://dx.doi.org/10.1016/S0168-1605(00)00451-7

Badrie, N., Gobin, A., Dookeran, S., \& Duncan, R. (2006). Consumer awareness and perception to food safety hazards in Trinidad, West Indies. Food Control, 17(5), 370-377. http://dx.doi.org/10.1016/j.foodcont.2005.01.003

Boodhu, A., Badrie, N., \& Sookdhan, J. (2008). Consumers' perceptions and awareness of safe food preparation practices at homes in Trinidad, West Indies. International Journal of Consumer Studies, 32, 41-48.

Bruhn, C. M., \& Schutz, H. G. (1999). Consumer food safety knowledge and practices. Journal of Food Safety, 19(1), 73-87. http://dx.doi.org/10.1111/j.1745-4565.1999.tb00235.x

Cody, M. M., \& Hogue, M. A. (2003). Results of the home food safety- It is in your hands 2002 survey: 
Comparisons to the 1999 benchmark survey and healthy people 2010 food safety behaviors objective. Journal of the American Dietetic Association, 103, 1115-1125. http://dx.doi.org/10.1016/S0002-8223(03)01064-2

EUFIC (The European Food Information Council). (2010). Retrieved from http://www.eufic.org/article/en/food-safety-quality/safe-food-handling/expid/basics-food-safety/

Fein, S. B., Jordan-Lin, C. T., \& Levy, A. S. (1995). Foodborne illness: perceptions, experiences, and preventative behaviors in the United States. Journal of Food Protection, 58, 1405-1411.

Fight BAC. (2010). Retrieved from http://www.fightbac.org

Jevšnik, M., Hlebec, V., \& Raspor, P. (2008). Consumers' awareness of food safety from shopping to eating. Food Control, 19, 737-745. http://dx.doi.org/10.1016/j.foodcont.2007.07.017

Knight, P. G., Jackson, J. C., Bain, B., \& Eldemire-Shearer, D. (2003). Household food safety awareness of selected urban consumers in Jamaica. International Journal of Food Sciences and Nutrition, 54(4), 309-320. http://dx.doi.org/10.1080/09637480120092107

Li-Cohen, A. E., \& Bruhn, C. M. (2002). Safety of consumer handling of fresh produce from the time of purchase to the plate: a comprehensive consumer survey. Journal of Food Protection, 65(8), 1287-1296.

McCarthy, M., Brennan, M., Kelly, A. L., Ritson, C., De Boer, M., \& Thompson, N. (2007). Who is at risk and what do they know? Segmenting a population on their food safety knowledge. Food Quality and Preference, 18(2), 205-217. http://dx.doi.org/10.1016/j.foodqual.2005.10.002

Odwin, R., \& Badrie, N. (2008). Consumers' perceptions and awareness of food safety practices in Barbados and Trinidad, West Indies - a pilot study. International Journal of Consumer Studies, 32, 394-398. http://dx.doi.org/10.1111/j.1470-6431.2008.00675.x

Redmond, E. C., \& Griffith, C. J. (2003). Consumer food handling in the home: a review of food safety studies. Journal of Food Protection, 66(1), 130-161.

U.S. Food and Drug Administration. (2006). FDA/FSIS food safety survey topline frequency report. Retrieved from http://www.fda.gov/Food/ScienceResearch/

Unusan, N. (2007). Consumer food safety knowledge and practices in the home in Turkey. Food Control, 18, 45-51. http://dx.doi.org/10.1016/j.foodcont.2005.08.006

WHO (World Health Organization). (2010). Retrieved from http://www.who.int/mediacentre/factsheets/fs237/en/print.html

Worsfold, D., \& Griffith, C. (1997). Food safety behavior in the home. British Food Journal, 99(3), 97-104. http://dx.doi.org/10.1108/00070709710168932

Zhang, Y., Lando, A., Estrin, A., \& Levy, A. (2010). Comparisons of food safety practices between U.S. and Costa Rica. US Department of Agriculture Food Safety Education Conference, Atlanta, GA, Mar. 23-26, Retrieved from http://www.fsis.usda.gov/News_\&_Events/2010_FSE_Conference_Presentations/index.asp

\section{Note}

Note 1. The Mann-Whitney U Test results with respect to "gender", Kruskal-Wallis Test results with respect to "age", "income", and "education", and the list of significant differences between the "experienced" and the "inexperienced" with respect to their safe food handling awareness, knowledge, and practices can be obtained from the author, upon request. 